\title{
Co-variation in soil biodiversity and biogeochemistry in northern and southern Victoria Land, Antarctica
}

\author{
Byron J. Adams \\ byron_adams@byu.edu \\ J. E. Barrett \\ Ross A. Virginia \\ Diana H. Wall \\ S. C. Cary
}

See next page for additional authors

Follow this and additional works at: https://scholarsarchive.byu.edu/facpub

Part of the Microbiology Commons

\section{Original Publication Citation}

Barrett, J. E., R. A. Virginia, D. H. Wall, S. C. Cary, B. J. Adams, A. L. Hacker, and J.M. Aislabie, "Co-variation in soil biodiversity and biogeochemistry in northern and southern Victoria Land, Antarctica," Antarctic Science 18(4) (26, 535-548.

\section{BYU ScholarsArchive Citation}

Adams, Byron J.; Barrett, J. E.; Virginia, Ross A.; Wall, Diana H.; Cary, S. C.; Hacker, A. L.; and Aislabie, J. M., "Co-variation in soil biodiversity and biogeochemistry in northern and southern Victoria Land, Antarctica" (2006). Faculty Publications. 296.

https://scholarsarchive.byu.edu/facpub/296

This Peer-Reviewed Article is brought to you for free and open access by BYU ScholarsArchive. It has been accepted for inclusion in Faculty Publications by an authorized administrator of BYU ScholarsArchive. For more information, please contact ellen_amatangelo@byu.edu. 
Authors

Byron J. Adams, J. E. Barrett, Ross A. Virginia, Diana H. Wall, S. C. Cary, A. L. Hacker, and J. M. Aislabie 


\title{
Co-variation in soil biodiversity and biogeochemistry in northern and southern Victoria Land, Antarctica
}

\author{
J.E. BARRETT ${ }^{1}$, R.A. VIRGINIA ${ }^{1}$, D.H. WALL², S.C. CARY ${ }^{3,5}$, B.J. ADAMS ${ }^{4}$, A.L. HACKER ${ }^{5}$ and \\ J.M. AISLABIE6 \\ ${ }^{1}$ Environmental Studies Program, Dartmouth College, Hanover, NH 03755, USA \\ ${ }^{2}$ Natural Resource Ecology Laboratory, Colorado State University, Fort Collins, CO 80523, USA \\ ${ }^{3}$ College of Marine Studies, University of Delaware, Lewes, DE 19958, USA \\ ${ }^{4}$ Microbiology and Molecular Biology and Evolutionary Ecology Laboratories, Brigham Young University, Provo, UT 84602, USA \\ ${ }^{5}$ University of Waikato, Private Bag 3105, Hamilton, New Zealand \\ ${ }^{6}$ Landcare Research, Private Bag 3127, Hamilton, New Zealand. \\ *Corresponding author: John.E.Barrett@Dartmouth.edu
}

\begin{abstract}
Data from six sites in Victoria Land $\left(72-77^{\circ} \mathrm{S}\right)$ investigating co-variation in soil communities (microbial and invertebrate) with biogeochemical properties showthe influence of soil properties on habitat suitability varied among local landscapes as well as across climate gradients. Species richness of metazoan invertebrates (Nematoda, Tardigrada and Rotifera) was similar to previous descriptions in this region, though identification of three cryptic nematode species of Eudorylaimus through DNA analysis contributed to the understanding of controls over habitat preferences for individual species. Denaturing Gradient Gel Electrophoresis profiles revealed unexpectedly high diversity of bacteria. Distribution of distinct bacterial communities was associated with specific sites in northern and southern Victoria Land, as was the distribution of nematode and tardigrade species. Variation in soil metazoan communities was related to differences in soil organic matter, while bacterial diversity and community structure were not strongly correlated with any single soil property. There were no apparent correlations between metazoan and bacterial diversity, suggesting that controls over distribution and habitat suitability are different for bacterial and metazoan communities. Our results imply that top-down controls over bacterial diversity mediated by their metazoan consumers are not significant determinants of bacterial community structure and biomass in these ecosystems.
\end{abstract}

Received 24 May 2006, accepted 16 August 2006

Key words: habitat suitability, invertebrate diversity, Latitudinal Gradient Project, microbial diversity, nematodes

\section{Introduction}

Terrestrial ecosystems along the Antarctic Victoria Land coast, from the McMurdo Dry Valleys in the south $\left(78-76^{\circ} \mathrm{S}\right)$ to Cape Adare $\left(71^{\circ} \mathrm{S}\right)$ in the north, occur across broad scale gradients of biodiversity, climate, and soil properties (Barrett et al. 2006). Insights into the relationships between biodiversity, productivity and ecosystem functioning may be especially discernable in Victoria Land since this region spans a range of ecosystems with no conspicuous source of organic matter and no metazoans, to those with abundant moss, lichen and algal biomass, marine-derived organic matter deposits and complex soil food webs (Rudolph 1963, Freckman \& Virginia 1997, Bargagli et al. 1999, Porazinska et al. 2002, Sinclair et al. 2003). This latitudinal gradient of varying soils and biota can be used to test specific hypotheses about the distribution of soil biodiversity and physical and biogeochemical controls over habitat suitability (HowardWilliams et al. 2006).

Little is known about the composition of Antarctic soil microbial communities, and the environmental factors that drive their patterns of diversity. Until quite recently, the low sensitivity of microbial techniques provided only a limited view of microbial communities, but more sophisticated techniques are now revealing more diverse communities than previously recognized (Cowan et al. 2002, Adams et al. 2006, Aislabie et al. 2006, Connell et al. 2006). Victoria Land invertebrate communities are comprised of five phyla of invertebrates: Arthropoda (Collembola, Acari), Tardigrada, Nematoda, Rotifera, and Protozoa (Adams et al. 2006). Diversity within these invertebrate taxa is typically among the lowest on Earth (less than five species). Freeliving soil nematodes and tardigrades are the most abundant and widely distributed animals in continental Antarctica (Freckman \& Virginia 1997, Petz 1997, Sinclair 2001, Convey \& Wynn-Williams 2002, Sohlenius et al. 2004, Convey \& McInnes 2005, Adams et al. 2006).

The suitability of Antarctic soil environments as habitats for soil biota occur across a range of biogeochemical properties and climate (Freckman \& Virginia 1997, Virginia \& Wall 1999). Courtright et al. (2001) formalized a habitat suitability model for metazoan invertebrates by quantifying 


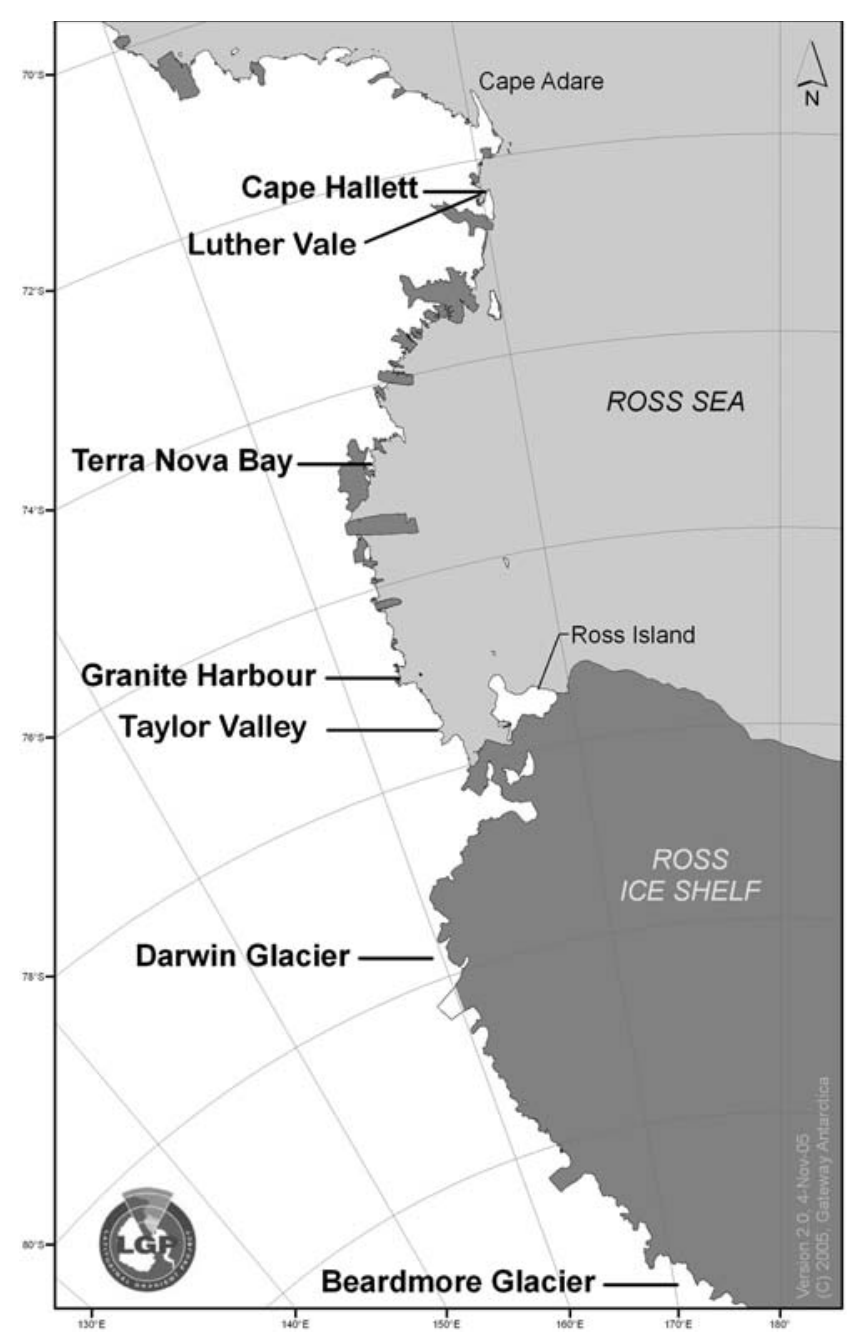

Fig. 1. Map of Victoria Land showing the locations of Cape Hallett, Luther Vale and Taylor Valley.

species abundance, life stages and their relation to a suite of soil biogeochemical properties with factor analysis. This model segregates metazoan communities into distinct habitats according to a combination of soil properties, most particularly moisture, organic matter and salinity. More recent work has synthesized these results together with a large number of observations in the Dry Valleys (Freckman \& Virginia 1997, Powers et al. 1998, Treonis et al. 1999, Gooseff et al. 2003, Moorhead et al. 2003, Barrett et al. 2004, Parsons et al. 2004, Nkem et al. 2006) in a numerical

Table I. Location of study sites in Victoria Land Antarctica.

\begin{tabular}{lrrrcc}
\hline Location & Latitude & Longitude Elevation & $\begin{array}{c}\text { Mean annual } \\
\text { temperature }\end{array}$ & $\begin{array}{c}\text { Mean DJF } \\
\text { temperature }\end{array}$ \\
\hline Taylor Valley & $77^{\circ} \mathrm{S}$ & $162^{\circ} \mathrm{E}$ & 50 & -20 & -5 \\
Luther Vale & $72^{\circ} 22^{\prime} \mathrm{S}$ & $169^{\circ} 53^{\prime} \mathrm{E}$ & 150 & $\mathrm{NA}$ & $\mathrm{NA}$ \\
Cape Hallett & $72^{\circ} 19^{\prime} \mathrm{S}$ & $170^{\circ} 13^{\prime} \mathrm{E}$ & 10 & -15 & -1 \\
\hline
\end{tabular}

$\mathrm{DJF}=$ December, January and February, i.e. the austral summer. $\mathrm{NA}=$ not available. model based upon logistic regression (Poage et al. unpublished). This model predicts probabilities for the presence of various nematode species and species combinations based upon a small number of chemical parameters (salinity, moisture, carbon, nitrogen, $\mathrm{pH}$ ) with high statistical significance.

Here we report on work conducted at six sites in northern and southern Victoria Land (Fig. 1), Antarctica in December and January of 2003-2004 (Table I). We investigated the structure (bacterial and metazoan diversity) and functioning (soil respiration) of soil communities and the influence of soil biogeochemical properties (organic matter, inorganic nutrients, physicochemical properties) on habitat suitability. The objective of this study was to investigate controls over the distribution and diversity of soil biota and their activity by quantifying co-variation in soil microbial and metazoan communities with soil biogeochemical properties among local landscapes and across broad climatic gradients in Victoria Land.

\section{Materials and methods}

\section{Site descriptions}

Taylor Valley $\left(77^{\circ} \mathrm{S}, 162^{\circ} \mathrm{E}\right.$, Fig. 1) is the principal site of the McMurdo Dry Valleys Long-Term Ecological Research programme. Arid soils are the most extensive landform of Taylor Valley, occupying $>95 \%$ of glacier ice-free surfaces below $1000 \mathrm{~m}$ (Burkins et al. 2001). Due to low precipitation $\left(<10 \mathrm{~cm}\right.$ water equivalent $\left.\mathrm{yr}^{-1}\right)$, relative humidity and soil temperatures, availability of liquid water is extremely limited and confined to brief periods during the summer when temperatures exceed freezing (Campbell \& Claridge 1982, Doran et al. 2002). Consequentially, surface soil moisture content is typically quite low $(<2 \%$ by weight), and is an important limitation over biotic community structure (Treonis et al. 1999, Aislabie et al. 2006), and the functioning of soil biota (Treonis et al. 2000, Barrett et al. 2006, Elberling et al. 2006, Gregorich et al. 2006).

Sources of organic matter contributing to Taylor Valley food webs include low rates of $\mathrm{C}$-fixation by photoautotrophic communities inhabiting the surface layers of sandstones and granites, i.e. endolithic communities and lichens (Friedmann et al. 1993, Kappen et al. 1998), microbial mats, lichens and mosses occupying intermittently saturated zones on stream and lake margins (Schwartz et al. 1992, Pannewitz et al. 2003), and ancient organic matter entrained in lacustine and marine sediments deposited during high stands of proglacial lakes or marine incursions (Burkins et al. 2000). Microbial mats (e.g. Phormidium spp., Nostoc spp.) and moss communities (e.g. Byrum spp., Hennediella heimii (Hedw.) Zand.) dominate $\mathrm{C}$ cycling and ecosystem processes where they occur (e.g. Schwartz et al. 1992, 1993, Pannewitz et al. 2003, Moorhead et al. 2003), but are confined to areas where 
significant liquid water is often available.

Cape Hallett $\left(72^{\circ} 19^{\prime} \mathrm{S}, 170^{\circ} 13^{\prime} \mathrm{E}\right)$ is a small, coastal, icefree area (72 ha) in northern Victoria Land $100 \mathrm{~km}$ south of Cape Adare (Fig. 1). with mean annual temperatures of $-15.3^{\circ} \mathrm{C}$ and annual precipitation of $18 \mathrm{~cm}$ of water equivalent per year (Duphorn 1981). About half of the total area of Cape Hallett is occupied by an Adélie penguin (Pygoscelis adeliae (Hombron \& Jacquinot)) rookery on the low-lying coastal areas (Seabee Spit) and skua (Catharacta maccormicki Saunders) colonies on the lower portions of an adjacent scree slope (Raytheon Polar Services Company 2003). The Cape Hallett landscape consists of basalt screes and moraines colonized by dense moss beds (Byrum spp.), green algae (Praisola spp.) and conspicuous lichen colonies, particularly in the Willett Cove area (Rudolph 1963, Pannewitz et al. 2005). Sources of soil moisture include precipitation, melting of snowfields, and the Bornmann Glacier above the scree slopes. Campbell \& Claridge (1987) emphasized that there is higher moisture availability in Cape Hallett soils compared to sites in southern Victoria Land, because in coastal zones of northern Victoria Land snow tends to melt rather than sublimate.

Other ice-free terrestrial environments in northern Victoria Land are found in the vicinity of Cape Hallett in dry cirques and saddles of the Admiralty and Victoria mountain ranges that serve as northern analogues of lessmarine influenced terrestrial environments in southern Victoria Land, i.e. the McMurdo Dry Valleys. An unnamed bowl-shaped valley north-east of Luther Peak is such a location (Fig. 1). The soils of this area, hereafter "Luther Vale", occupy approximately 100 ha at $200 \mathrm{~m}$ a.s.1. and are underlain by metamorphic rock. Observed sources of water include precipitation and meltwater from snowfields on the north-western side of Luther Peak, which contribute to an ice covered pond.

\section{Sample collection}

We identified two sites at each of the three locations across Victoria Land (i.e. Taylor Valley, Cape Hallett, Luther Vale) that differed in conspicuous soil features that influence soil biology, and therefore represented areas of low and high potential productivity, based upon a priori assessment. Transects $(20 \mathrm{~m})$ were sampled at randomly determined points at each of these sites. In Taylor Valley, four replicate transects were established at varying distances from two glacial meltwater streams in the Lake Fryxell basin; each transect covered similar topography (i.e. distance from stream, surface soil conditions), and was perpendicular to the axis of stream flow of Von Guerard Stream and Green Creek. Green Creek is among the most diverse and biologically active sites in the Taylor Valley with regard to colonization by microbial mats and mosses, while Von Guerard is characterized by lower density of microbial mats and little to no moss colonization (Alger et al. 1997,
McKnight et al. 2004). Likewise, in Luther Vale, four replicate transects were established at sites on the north and south sides of an unnamed meltwater pond; each transect covered similar elevation, slope, and aspect at locations of varying distances from the pond-soil margin. At Cape Hallett, only two transects were sampled at each of two sites (in order to minimize disturbance in the ASPA 106), where transects were established at various distances from recently abandoned penguin mounds (SeaBee Spit), and in mossdominated soils (Willett Cove).

Five replicate samples were collected from the surface soil $(0-10 \mathrm{~cm})$ of each transect along the productivity gradients in the study sites located in Taylor Valley, Cape Hallett and Luther Vale $(n=100)$. Soil samples were collected using standard aseptic protocols developed in the dry valleys (Freckman \& Virginia 1997). Samples were split in the field to provide material for invertebrate and chemical analyses, and for assessment of bacterial diversity. Subsamples for bacterial analysis were collected in duplicate from excavated soil profiles (see below).

\section{Soil $\mathrm{CO}_{2}$ flux}

Soil $\mathrm{CO}_{2}$ flux, i.e. soil respiration across the sites to provide a comparative index of ecosystem functioning was measured using a portable gas exchange system (LiCor 6400 Portable Photosynthesis System with 6400-09 soil $\mathrm{CO}_{2}$ flux chamber, LiCor Inc., Lincoln, NE) customized to measure small changes in $\mathrm{CO}_{2}$ (Parsons et al. 2004). Soil temperature (5 cm depth) was measured continually using Hobo temperature loggers (Onset Computer Corp, Bourne, $\mathrm{MA})$. We measured soil $\mathrm{CO}_{2}$ flux over the course of two days at each site, with the exception of the Von Guerard site where equipment malfunction stopped data collection after $24 \mathrm{hr}$. Here we report midday averages of measurement taken from 12 replicate plots at each site.

\section{Soil chemical analysis}

Field moist samples were passed through a \#10 sieve and the $<2 \mathrm{~mm}$ fraction retained for analysis. Gravimetric soil moisture, conductivity, $\mathrm{pH}$ and inorganic $\mathrm{N}$ were determined using conventional techniques modified for dry valley soils (Barrett et al. 2002). We determined the elemental concentration and natural abundance of $\mathrm{C}$ and $\mathrm{N}$ isotopes in acidified soils using an a Delta-Plus XL isotope ratio mass spectrometer interfaced with a Carlo Erba 1500 elemental analyser at Dartmouth College.

\section{Soil metazoans}

Nematodes, rotifers and tardigrades were extracted from unsieved soil samples using a sugar-centrifugation technique modified for Antarctic soils (Freckman \& Virginia 1997). Nematodes were identified under light 
microscopy based upon morphology and enumerated to species, sex and life stage; densities of tardigrades and rotifers were enumerated. Presence of collembolans and mites were noted, both in the field and in the extractions. The presence of cryptic species was explored via DNA analysis.

DNA was extracted from individual metazoans using DNeasy tissue kits (Qiagen Inc, Valencia, CA). Ribosomal DNA of the internally transcribed spacer 1 region was PCR amplified using the $18 \mathrm{~S}$ primer designed by Vrain et al. (1992) and the reverse primer of Cherry et al. (1997). Ribosomal DNA of the D2D3 region was amplified and sequenced using the 500-501 primer set of Nadler et al. (2000). The ribosomal small subunit was amplified and sequenced using the 1A 3B primer set of Baldwin et al. (1997). PCR reactions were carried out in $25 \mu$ l volumes. Each reaction contained: $2.5 \mu \mathrm{l} 10 \mathrm{xPCR}$ buffer, $1.5 \mu \mathrm{l}$ $\mathrm{MgCl}_{2}, 1 \mu \mathrm{l}$ dNTP mixture (10 mM each), $1 \mu \mathrm{l}$ of $10 \mathrm{pM}$ forward primer, $1 \mu \mathrm{l}$ of $10 \mathrm{pM}$ reverse primer, $0.25 \mu \mathrm{l}$ of high fidelity DNA polymerase (Enzypol Ltd, London, Ontario, Canada), $19.55 \mu \mathrm{l}$ of distilled water and $5 \mu \mathrm{l}$ of

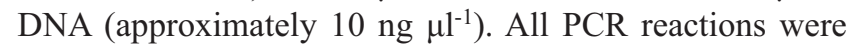
run in a PTC-100 Thermocycler (MJ Research Inc, Waltham, MA) with the following cycling profile: 1 cycle of $94^{\circ} \mathrm{C}$ for $7 \mathrm{~min}$ followed by 40 cycles of $94^{\circ} \mathrm{C}$ for $1 \mathrm{~min}$, $50^{\circ} \mathrm{C}$ for $1 \mathrm{~min}, 72^{\circ} \mathrm{C}$ for $1 \mathrm{~min}$. The last cycle was followed by a lengthened primer extension period $\left(72^{\circ} \mathrm{C}\right.$ for $\left.10 \mathrm{~min}\right)$. PCR products were prepared for sequencing reactions by enzymatic treatment (ExoSap, GE Healthcare, Piscataway, NJ) and sequenced at the Brigham Young University DNA Sequencing Center on Perkin-Elmer/Applied Biosystems automated DNA sequencers. The resulting DNA sequences were used to reconstruct evolutionary relationships, identify independently evolving lineages and inform species delimitation (Wiley 1978, Lynch \& Renjifo 1990, Frost \& Kluge 1994, Adams 1998, 2001, Lynch 1999, Wiley \& Mayden 2000). These lineages also correspond with the MOTU concept (Floyd et al. 2002, Eyualem \& Blaxter 2003, Blaxter et al. 2005), in that there are more than three nucleotide differences (in most cases many more) at the SSU locus between "species".

Shannon-Weiner diversity indices (H') were calculated for nematodes using the equation:

$$
H^{\prime}=-\sum_{i=1}^{s} p_{i} \ln p_{i}
$$

where $p_{\mathrm{i}}$ is the proportion of the $i$ th species and $s$ is the number of species present in a given soil community. Only nematodes were present in sufficient abundance and diversity necessary to calculate Shannon-Weiner indices.

\section{Microbial biomass and bacterial diversity}

Microbial biomass was estimated using the chloroform fumigation-extraction (Cheng \& Virginia 1993) modified for the low biomass of Antarctic soils. Soils were fumigated with distilled chloroform in a vacuum desiccator cabinet at 65 mbar vacuum for five days. On day 5 , pairs of fumigated and unfumigated soils were extracted in $0.5 \mathrm{M} \mathrm{K}_{2} \mathrm{SO}_{4}$, filtered through Whatman \#42 filters, acidified with $200 \mu \mathrm{l}$ concentrated $\mathrm{HCl}$ and frozen prior to analysis of total organic $\mathrm{C}$ and total $\mathrm{N}$ on a Schimadzu TOC analyser at the Crary Laboratory at McMurdo Station. Microbial biomass $\mathrm{C}$ and $\mathrm{N}$ was calculated as the difference between the chloroform-labile $\mathrm{C}$ in the pairs of fumigated and unfumigated soils.

Nucleic acids were extracted from soil using a modified cetyltrimethyl-ammonium bromide-polyvinylpyrrolidone$\beta$ mercaptoethanol (CTAB) extraction protocol (Coyne et al. 2001) designed for maximum recovery of nucleic acids from low biomass silica-rich soils. Soils $(0.7 \mathrm{~g})$ were aseptically measured into $1.5 \mathrm{ml}$ tubes containing $0.5 \mathrm{~g}$ each $0.1 \mathrm{~mm}$ and $2.5 \mathrm{~mm}$ zirconia/silica beads (Biospec Products Inc, Bartlesville, OK). Beads were baked at $250^{\circ} \mathrm{C}$ for 2 hours prior to use. A $300 \mu$ phosphate buffer $(100 \mathrm{mM}$ $\mathrm{NaH} 2 \mathrm{PO} 4)$, and $300 \mu \mathrm{l}$ SDS lysis buffer $(100 \mathrm{mM} \mathrm{NaCl}$, $500 \mathrm{mM}$ Tris $\mathrm{pH} 8.0,10 \% \mathrm{SDS}$ ) were added to the tubes. A Fast Prep ${ }^{\circledR}$ FP120 cell disrupter was used at $4.0 \mathrm{~ms}^{-1}$ for $30 \mathrm{sec}$ to lyse the cells. Samples were then centrifuged at $13200 \mathrm{rpm}$ for $3 \mathrm{~min}$. The supernatant was removed and transferred to a $1.5 \mathrm{ml}$ sterile Eppendorf tube containing $200 \mu \mathrm{l}$ CTAB buffer $(100 \mathrm{mM}$ Tris- $\mathrm{HCl}, 1.4 \mathrm{M}$ $\mathrm{NaCl}, 20 \mathrm{mM}$ EDTA, 2\% CTAB, 1\% PVP, 0.4\% BME). Samples were incubated at $100 \mathrm{rpm}$ and $60^{\circ} \mathrm{C}$ for $30 \mathrm{~min}$. Subsequent to incubation, $1000 \mu \mathrm{l}$ chloroform:isoamyl alcohol (24:1) was added to each sample. Samples were mixed by repeated inversion, vortexed for $15 \mathrm{sec}$ and then centrifuged at $13200 \mathrm{rpm}$ for $5 \mathrm{~min}$. The upper aqueous layer was removed into a sterile $1.5 \mathrm{ml}$ Eppendorf tube.

An additional chloroform extraction was performed by adding $500 \mu \mathrm{l}$ chloroform:isoamyl alcohol (24:1), vortexing the samples for 10 seconds followed by incubation on a rocking bed for $20 \mathrm{~min}$ at room temperature. Samples were then centrifuged at $13200 \mathrm{rpm}$ for $5 \mathrm{~min}$ and the upper aqueous layer was removed into a $1.5 \mathrm{ml}$ sterile Eppendorf tube. DNA was precipitated for at least one hour at $-80^{\circ} \mathrm{C}$ with the addition of ammonium acetate to a final concentration of $2.5 \mathrm{M}$ and 0.54 volume isopropyl alcohol. Samples were then centrifuged at $13200 \mathrm{rpm}$ for $20 \mathrm{~min}$ and the DNA pellet was washed with $1 \mathrm{ml} 70 \%$ ethanol and air dried in a laminar flow hood for 1 hour. DNA was resuspended in $20 \mu \mathrm{l}$ sterile LO-TE $(3 \mathrm{mM}$ Tris- $\mathrm{HCl} \mathrm{pH}=$ $8,0.2 \mathrm{mM}$ EDTA) and stored at $-80^{\circ} \mathrm{C}$ until use. The yield and quality of each DNA preparation was evaluated through visualization on a $1 \%$ agarose gel and quantified using a NanoDrop ND-1000 spectrophotometer at $260 \mathrm{~nm}$ (NanoDrop Technologies, Montchanin, DE).

Bacterial communities were examined using denaturing gradient gel electrophoresis (DGGE, Muyzer et al. 1993) in order to obtain a fingerprint of the microbial populations 
present within the individual soil samples. Although it is subject to biases of the PCR (Suzuki \& Giovannoni 1996, Polz \& Cavanaugh 1998), DGGE is capable of resolving DNA fragments differing by a single base pair (Myers et al. 1988, Lessa \& Applebaum 1993) and detecting amplicons comprising $\geq 1 \%$ of the total community (Muyzer et al. 1993, Lee et al. 1996, Murray et al. 1996). For bacterial DGGE analysis, the $\mathrm{V} 3$ region $(\sim 180 \mathrm{bp})$ of the bacterial 16S rDNA genes present in soil samples was amplified using PCR (Saiki et al. 1988) with primers 338F/GC clamp and 519RC as described by Muyzer et al. (1993). For each sample, 3-25 $\mu$ l reactions were pooled. Amplifications were performed using $10 \mathrm{ng}$ template DNA, 1x JumpStart PCR Buffer (Sigma, St. Louis, MO), $0.2 \mathrm{mM}$ each deoxyribonucleotide triphosphate (dNTP), $2.5 \mathrm{mM} \mathrm{MgCl}$, 4\% DMSO, $0.2 \mu \mathrm{M}$ (each) primer, and 0.5U JumpStart Taq polymerase (Sigma). Three PCA amplifications from each template were performed on a PTC-200 Thermocycler (MJ Research Inc, Waltham, MA) using the following hot start (D'Aquila et al. 1991) touchdown protocol: $94^{\circ} \mathrm{C}$ for $2 \mathrm{~min}$, followed by 30 cycles of $94^{\circ} \mathrm{C}$ for $0.5 \mathrm{~min}, 65^{\circ} \mathrm{C}\left(-0.5^{\circ} \mathrm{C}\right.$ per cycle until $55^{\circ} \mathrm{C}$ was reached) for $0.5 \mathrm{~min}$, and $72^{\circ} \mathrm{C}$ for 1 min with a final elongation step consisting of $72^{\circ} \mathrm{C}$ for $7 \mathrm{~min}$. Each set of amplifications was subsequently pooled for each template and evaluated through visualization on a $1 \%$ agarose gel, purified using a QIAquick PCR Purification Kit (Qiagen) and quantified spectrophotometrically as above.

For microbial community DGGE analysis, the PCR products were separated on an 8\% acrylamide gel (37.5:1 ratio of arylamide-bisacrylamide) with a $30 \%$ to $70 \%$ gradient of denaturant ( $7 \mathrm{M}$ urea and $40 \%$ formamide). For each sample, $400 \mathrm{ng}$ of purified PCR product was loaded and run. Additionally, a repeatable standard (300 ng pooled PCR products from three known bacterial isolates) was loaded into lanes on opposite sides of the gel for normalization. All gels were electrophoresed for $5 \mathrm{hr}$ $(130 \mathrm{~V})$ at $60^{\circ} \mathrm{C}$ in $1 \mathrm{X}$ TAE buffer $(40 \mathrm{mM}$ Tris base, $20 \mathrm{mM}$ sodium acetate, $1 \mathrm{mM}$ EDTA) on a DCode Universal Mutation Detection System (Bio-Rad, Hercules, CA). Gels were stained with ethidium bromide $\left(1 \mu \mathrm{g} \mathrm{mL}^{-1}\right)$ for $30 \mathrm{~min}$, destained in sterile water for $20 \mathrm{~min}$, visualized under UV and digitally photographed using the AlphaImager imaging system (Alpha Innotech Corp, San Leandro, CA).

\section{Statistical analysis}

Estimates of nematode, rotifer and tardigrade abundance were $\log (\mathrm{x}+1)$ transformed to satisfy assumptions of normality and uniformity of variance. We performed conventional statistical analyses in SAS 9.1 to test for variation in soil biogechemical properties, invertebrate abundance and diversity among and within locations in northern and nouthern Victoria Land (Barrett et al. 2004, Table I). We used principal component analysis (PCA) to characterize the distribution of metazoan and bacteria across ranges of soil biogeochemical properties encountered among the locations sampled in Victoria Land (CANOCO v4.02, Ter Braak 1986). PCA was run on the entire metazoan, bacteria and soil biogeochemical dataset and also on the metazoan-biogeochemistry data independent of the bacterial data to facilitate comparison with earlier work in southern Victoria Land (Courtright et al. 2001, Barrett et al. 2004). Correlation coefficients of nematode species abundances were plotted against the principle components in species-environment bi-plots (Ter Braak 1986, Palmer 1993).

Images of DGGE bands were analysed using Gelcompar II ${ }^{\mathrm{TM}}$ (Applied Maths, Kortrijk, Belgium) to allow normalization, grouping and identification of electrophoresis banding patterns within and among samples and gels. Manual band detection was used with an approximate minimal profiling of $12 \%$ and a minimal area of $0.6 \%$. Similarities among tracks were calculated using the band-based similarity Dice coefficient with fuzzy logic. Based on these similarity coefficients, dendograms representing hierarchical linkage levels were constructed using the unweighted pair group method with arithmetic averages (UPGMA) clustering algorithm (Sokal \& Michener 1958).

\section{Results}

\section{Soil properties}

Soil biogeochemical and physical properties varied significantly among the locations and sites sampled. Mean

Table II. Mean soil organic matter and nutrient content ( \pm SE) at each site.

\begin{tabular}{|c|c|c|c|c|c|c|}
\hline Study site & Soil organic C & Total soil N & $\mathrm{C}: \mathrm{N}$ & $\begin{array}{l}\text { Microbial } \\
\text { biomass C }\end{array}$ & $\begin{array}{l}\text { Ammonium } \\
\left(\mathrm{NH}_{4}^{+}-\mathrm{N}\right)\end{array}$ & $\begin{array}{c}\text { Nitrate } \\
\left(\mathrm{NO}_{3}^{-}-\mathrm{N}\right) \\
\left.\mathrm{kg}^{-1}\right)\end{array}$ \\
\hline Von Guerard Stream & $0.29^{d} \pm 0.04$ & $0.08^{\mathrm{d}} \pm 0.01$ & $3.98 \pm 0.40$ & $8.2^{\mathrm{d}} \pm 1.0$ & $0.41^{\mathrm{c}} \pm 0.09$ & $4.43^{b} \pm 1.97$ \\
\hline Green Creek & $0.35^{\mathrm{d}} \pm 0.04$ & $0.09^{\mathrm{d}} \pm 0.01$ & $4.20 \pm 0.40$ & $13.1^{\mathrm{d}} \pm 1.5$ & $0.17^{\mathfrak{c}} \pm 0.06$ & $0.77^{\mathrm{c}} \pm 0.38$ \\
\hline Luther Vale North & $0.53^{\text {cd }} \pm 0.05$ & $0.19^{c} \pm 0.01$ & $2.69 \pm 0.10$ & $67.3^{c} \pm 5.6$ & $0.22^{\mathrm{c}} \pm 0.04$ & $0.02^{\mathrm{d}} \pm 0.01$ \\
\hline Luther Vale South & $0.69^{c} \pm 0.14$ & $0.24^{\mathfrak{c}} \pm 0.02$ & $2.48 \pm 0.30$ & $73.0^{c} \pm 9.5$ & $0.16^{\mathrm{c}} \pm 0.01$ & $0.18^{c} \pm 0.07$ \\
\hline Willett Cove & $17.05^{\mathrm{b}} \pm 1.80$ & $3.19^{b} \pm 0.29$ & $5.18 \pm 0.10$ & $204.8^{b} \pm 24.0$ & $4.57^{b} \pm 0.46$ & $2.94^{b} \pm 0.50$ \\
\hline SeaBee Spit & $21.90^{\mathrm{a}} \pm 1.28$ & $9.86^{\mathrm{a}} \pm 0.68$ & $2.26 \pm 0.10$ & $506.1^{\mathrm{a}} \pm 108.0$ & $718.40^{\mathrm{a}} \pm 39.00$ & $154.60^{\mathrm{a}} \pm 54.00$ \\
\hline
\end{tabular}

Note: superscripts denote significant differences among means. Sites with the same letter are not significantly different $(P<0.05)$. 


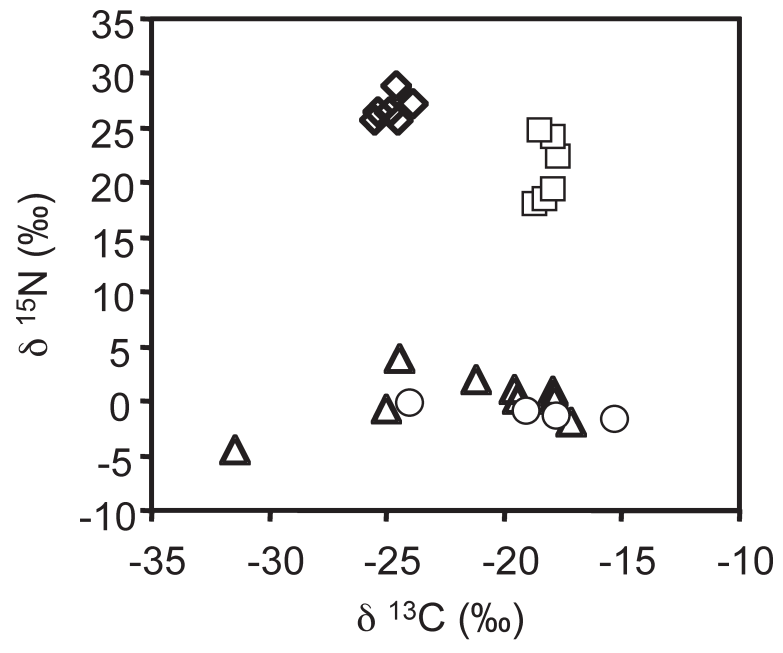

\section{$\Delta$ Taylor Valley $\square$ Willett Cove ○ Luther Vale $\diamond$ SeaBee Spit}

Fig. 2. Stable isotope bi-plot of Victoria Land soils.

moisture content was highest in soils collected from the sites at Cape Hallett $\left(9.47-25.87 \% \mathrm{~g} \mathrm{~g}^{-1}\right)$ relative to soils collected from sites in Luther Vale (3.91-4.66\% $\mathrm{g} \mathrm{g}^{-1}$ ) and Taylor Valley $\left(2.18-5.36 \% \mathrm{~g} \mathrm{~g}^{-1}, \mathrm{~F}=109.59, P<0.0001\right)$. Moisture content also varied significantly among transects within study sites, particularly in Green Creek $\left(1.11-15.58 \% \mathrm{~g} \mathrm{~g}^{-1}, \mathrm{~F}=12.07, P<0.0001\right)$. The most alkaline conditions were found in soils collected from Taylor Valley and Luther Vale $(\mathrm{pH}=9.5 \pm 0.1$ and $9.4 \pm$ 0.03, respectively), relative to soils from the sites in Cape Hallett, where $\mathrm{pH}$ was more variable and ranged from 5.3-8.4 (F = 333.53, $P<0.0001)$. Electrical conductivity of the soil varied among study sites from low values of $47-130 \mu \mathrm{S} \mathrm{cm}^{-1}$ in southern Luther Vale to $1200 \mu \mathrm{S} \mathrm{cm}^{-1}$ in marine influenced soils from Seabee Spit $(\mathrm{F}=17.87, P=$ $0.0001)$.

Soil organic matter varied significantly among the sites (Table II). Soils from Cape Hallett had organic C and total N concentrations an order of magnitude above soils from Taylor Valley and Luther Vale. Differences in organic matter $(\mathrm{C}$ and $\mathrm{N})$ concentrations among the sites were highly significant $(\mathrm{F}=141.32, P<0.0001, \mathrm{~F}=138.98$
Table III. Mean mid-day soil respiration and microclimate conditions ( \pm SD) at each site.

\begin{tabular}{lccc}
\hline Study site & Soil respiration & $\begin{array}{c}\text { Mid-day soil } \\
\text { temperature }(5 \mathrm{~cm}) \\
\left(\mu \mathrm{mol} \mathrm{CO} \mathrm{m}^{-2} \mathrm{~s}^{-1}\right)\end{array}$ & $\begin{array}{c}\text { Soil moisture } \\
\text { content } \\
\left(\% \mathrm{~g} \mathrm{~g}^{-1}\right)\end{array}$ \\
\hline Von Guerard Stream & $0.02 \pm 0.015^{\dagger}$ & 10.43 & $2.18^{\mathrm{d}} \pm 0.26$ \\
Green Creek & $0.31 \pm 0.14^{\mathrm{b}}$ & 13.62 & $5.36^{\mathrm{c}} \pm 1.52$ \\
Willett Cove & $0.51 \pm 0.23^{\mathrm{b}}$ & 9.31 & $25.87^{\mathrm{a}} \pm 1.16$ \\
SeaBee Spit & $2.43 \pm 0.96^{\mathrm{a}}$ & 9.31 & $9.47^{\mathrm{b}} \pm 1.01$ \\
\hline
\end{tabular}

Not included in ANOVA because of missing data

$P<0.0001)$. Patterns in microbial biomass $\mathrm{C}$ were similar to those of bulk soil organic $\mathrm{C}(\mathrm{F}=18.85, P<0.0001)$, with the highest levels of microbial biomass found in Cape Hallett soils, followed by Luther Vale and Taylor Valley soils. Nutrient concentrations also varied among the sites (Table II). The highest levels of soil $\mathrm{NH}_{4}^{+}$content were found at Cape Hallett $(\mathrm{F}=228.69, P<0.0001)$, particularly in the Seabee Spit site located near the penguin colony. Soil $\mathrm{NO}_{3}^{-}$concentrations were also highest in the Seabee Spit site, followed by the two most disparate sites, Von Guerard and Willett Cove where $\mathrm{NO}_{3}{ }^{-}$concentrations averaged 3-4.4 $\mathrm{mg} \mathrm{N} \mathrm{kg} \mathrm{soil}{ }^{-1}$ (Table II, $\mathrm{F}=7.08, P<0.0001$ ).

Stable isotopic composition of soil organic matter varied significantly among the study sites (Fig. 2, one-way ANOVA: $\mathrm{F}=281.65, P<0.00001$ and $\mathrm{F}=4.33, P=0.014$, for $\delta^{15} \mathrm{~N}$ and ${ }^{13} \mathrm{C} \%$, respectively). The greatest differences in stable isotope ratios were for $\mathrm{N}$, with the enriched ${ }^{15} \mathrm{~N} /{ }^{14} \mathrm{~N}$ ratios found in soils collected from Willett Cove and Seabee Spit, and relatively depleted values for soils from Taylor Valley and Luther Vale (Fig. 2). Ranges of ${ }^{13} \mathrm{C}$ content were more similar among soils from all locations; the most notable trends were tight clustering of ${ }^{13} \mathrm{C}$ values for soils from SeaBee Spit and Willett Cove (-24.8 and $-18.2 \delta{ }^{13} \mathrm{C} \%$, respectively), and broader ranges of ${ }^{13} \mathrm{C}$ contents for Luther Vale and Taylor Valley soils (-15 to -25 , and -17 to $-32, \%$, respectively, Fig. 2).

\section{Soil respiration}

Rates of midday soil respiration (Table III) in SeaBee Spit were an order of magnitude greater than any of the other sites $\left(2.43 \pm 0.96 \mu \mathrm{mol} \mathrm{CO} \mathrm{m}^{-2} \mathrm{~s}^{-1}\right)$. Soil respiration rates observed at the Von Guerard site were the lowest $(0.02 \pm$

Table IV. Abundance $\left(\# \mathrm{~kg} \mathrm{soil}^{-1}\right)$ of soil biota at each site (mean $\left.\pm \mathrm{SE}\right)$.

\begin{tabular}{|c|c|c|c|c|c|c|c|c|c|}
\hline \multirow[t]{2}{*}{ Study site } & \multirow[t]{2}{*}{ S. lindsayae } & \multicolumn{3}{|c|}{ Eudorylaimus } & \multirow{2}{*}{$\begin{array}{c}\text { Plectus } \\
\text { antarcticus }\end{array}$} & \multirow{2}{*}{$\begin{array}{c}\text { Panagrolaimus } \\
\text { davidii }\end{array}$} & \multirow[t]{2}{*}{ Rotatoria sp. } & \multirow{2}{*}{$\begin{array}{c}\text { Heterotardigrada } \\
\text { sp. }\end{array}$} & \multirow[t]{2}{*}{ Hypsibius sp. } \\
\hline & & sp. 1 & sp. 2 & sp. 3 & & & & & \\
\hline Von Guerard Stream & $1052^{a} \pm 348$ & $25^{\mathrm{b}} \pm 10$ & 0 & 0 & 0 & 0 & $19^{b} \pm 19$ & 0 & 0 \\
\hline Green Creek & $618^{\mathrm{ab}} \pm 155$ & $322^{a} \pm 213$ & 0 & 0 & $353^{a} \pm 171$ & 0 & $25^{\mathrm{b}} \pm 10$ & 0 & $24^{\mathrm{b}} \pm 10$ \\
\hline Luther Vale north & $336^{\mathrm{b}} \pm 76$ & 0 & $34^{\mathrm{b}} \pm 5$ & 0 & 0 & 0 & $1^{\mathrm{b}} \pm 1$ & 0 & 0 \\
\hline Luther Vale south & $247^{b} \pm 104$ & 0 & $60^{\mathrm{ab}} \pm 18$ & 0 & $6^{\mathrm{b}} \pm 4$ & 0 & $19^{\mathrm{b}} \pm 12$ & 0 & 0 \\
\hline Willett Cove & 0 & 0 & 0 & $36^{\mathrm{b}} \pm 11$ & $241^{\mathrm{a}} \pm 60$ & $788^{a} \pm 446$ & $5602^{\mathrm{a}} \pm 1865$ & $272^{\mathrm{a}} \pm 171$ & 0 \\
\hline SeaBee Spit & 0 & 0 & 0 & 0 & 0 & $122^{\mathrm{b}} \pm 40$ & $1^{\mathrm{b}} \pm 1$ & 0 & 0 \\
\hline
\end{tabular}


Table V. ANOVA values from general linear models partitioning variance encountered in soil biological properties among study sites and sampling transects.

\begin{tabular}{llrrrc}
\hline Variable & Source & df & F & $P$ & Partial $r^{2}$ \\
\hline Total & Site & 5 & 27.71 & $<0.0001$ & 0.50 \\
Scottnema lindsayae & Transect & 3 & 5.34 & 0.0021 & 0.058 \\
abundance & Site*transect & 11 & 3.93 & 0.0001 & 0.16 \\
& & & & & \\
Total & Site & 5 & 11.46 & $<0.0001$ & 0.17 \\
Eudorylaimus spp. & Transect & 3 & 43.63 & $<0.0001$ & 0.39 \\
abundance & Site*transect & 11 & 5.52 & $<0.0001$ & 0.18 \\
& & & & & \\
Total & Site & 5 & 24.83 & $<0.0001$ & 0.36 \\
Plectus antarcticus & Transect & 3 & 15.17 & $<0.0001$ & 0.13 \\
abundance & Site*transect & 11 & 6.24 & $<0.0001$ & 0.20 \\
& & & & & \\
Total & Site & 5 & 34.66 & $<0.0001$ & 0.59 \\
Panagrolaimus davidii & Transect & 3 & 2.87 & 0.042 & 0.029 \\
abundance & Site*transect & 11 & 3.13 & 0.0015 & 0.12 \\
& & & & & \\
Total & Site & 5 & 27.44 & $<0.0001$ & 0.49 \\
Rotifer & Transect & 3 & 2.01 & 0.12 & 0.019 \\
abundance & Site*transect & 11 & 4.67 & $<0.0001$ & 0.16 \\
Total & & & & & \\
Tardigrade & Site & 5 & 8.5 & $<0.0001$ & 0.23 \\
abundance & Transect & 3 & 0.48 & 0.70 & 0.01 \\
\hline & Site*transect & 11 & 4.96 & $<0.0001$ & 0.32 \\
\hline & & & & &
\end{tabular}

$0.015 \mu \mathrm{mol} \mathrm{CO}_{2} \mathrm{~m}^{-2} \mathrm{~s}^{-1}$ ), though these measurements were excluded from the ANOVA because of missing data following equipment malfunction in the field. Linear regression of means suggests that microbial biomass $\mathrm{C}$ $(\mathrm{MBC})$ is a significant factor influencing rates of soil respiration (respiration $=0.0045 * \mathrm{MBC}-0.0078, r^{2}=0.96$, $P<0.037)$. Similar regressions for total soil organic $\mathrm{C}$ and soil moisture content were not statistically significant $(P$ of linear regressions $=0.19$ and 0.92 , respectively).

\section{Metazoan diversity}

There were significant differences in soil metazoan community composition and population densities between the study sites (Tables IV \& V). Total metazoan richness increased from Taylor Valley in southern Victoria Land, to the northern sites in the vicinity of Cape Hallett, with the greatest diversity found in soils collected from the Willett Cove site at Cape Hallett (Fig. 3a, $\mathrm{F}=52.57, P<0.0001$ ). There were similarities in metazoan diversity among intermediate sites, particularly Green Creek and North Luther Vale (Table IV). Collembolans and mites were only observed in northern Victoria Land (Cape Hallett and Luther Vale), though their distribution is known to extend to sites colonized by moss and microbial mat communities previously described in the Dry Valleys (Schwartz et al. 1993, Adams et al. 2006).

Distribution of tardigrades was limited to wet sediments, and were found only in soils collected from the Green Creek
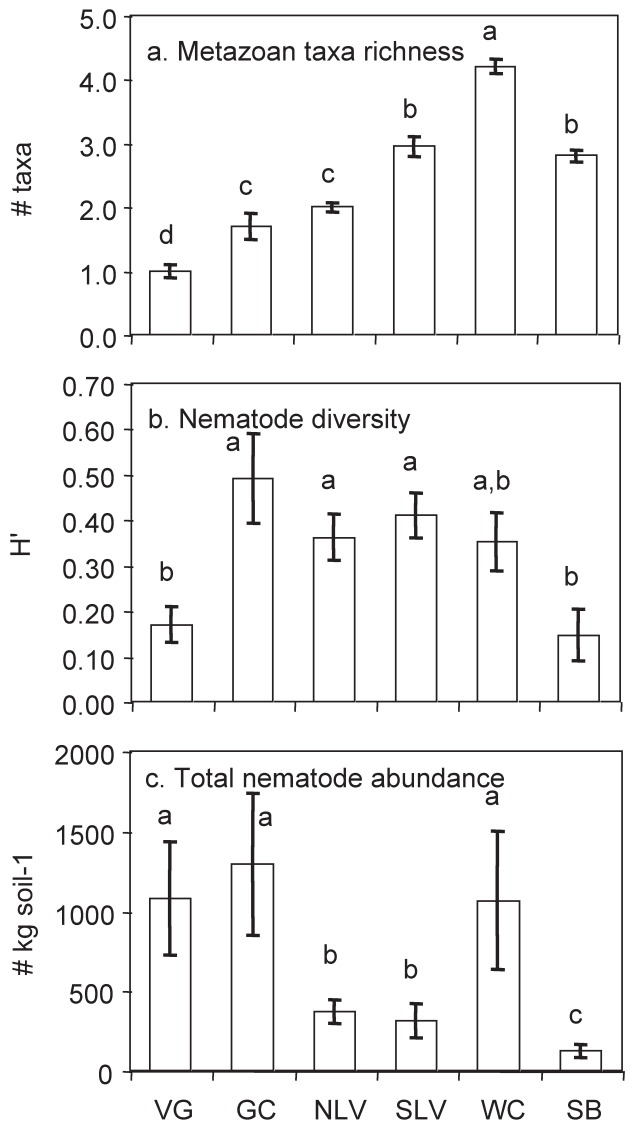

Fig. 3. Richness, Shannon-Wiener diversity and abundance of selected soil biota.

and Willett Cove sites. (Table IV). Rotifers (Rotatoria sp.) were ubiquitous across the study sites (though they were present in very low numbers in Luther Vale and SeaBee Spit), with the greatest abundances observed in soil from the Willett Cove site on Cape Hallett where population densities were more than five times greater than other metazoan populations (Table IV). DNA analyses of local tardigrade and rotifer communities confirmed morphological observations that they were dominated by single species. The tardigrade Hypsibius sp. was present at the Green Creek site, while an unknown member of the Heterotardigrada dominated the Willett Cove site (Table IV).

Nematode diversity (H') was lowest at the extreme ends of the soil productivity gradient at Von Guerard Stream in Taylor Valley and from the most organic rich soils on SeaBee Spit at Cape Hallett (Fig. 3b, F = 9.36, $P<0.0001$ ). DNA sequence profiles of three out of four of the nematode species encountered were congruent with morphological observations (e.g. Andrassy 1998). However, based on DNA sequences of the small and large ribosomal subunits (SSU, LSU), our data indicate that Eudorylaimus is represented by at least three species, which we describe as follows: Eudorylaimus sp.1 was isolated from soils in the 


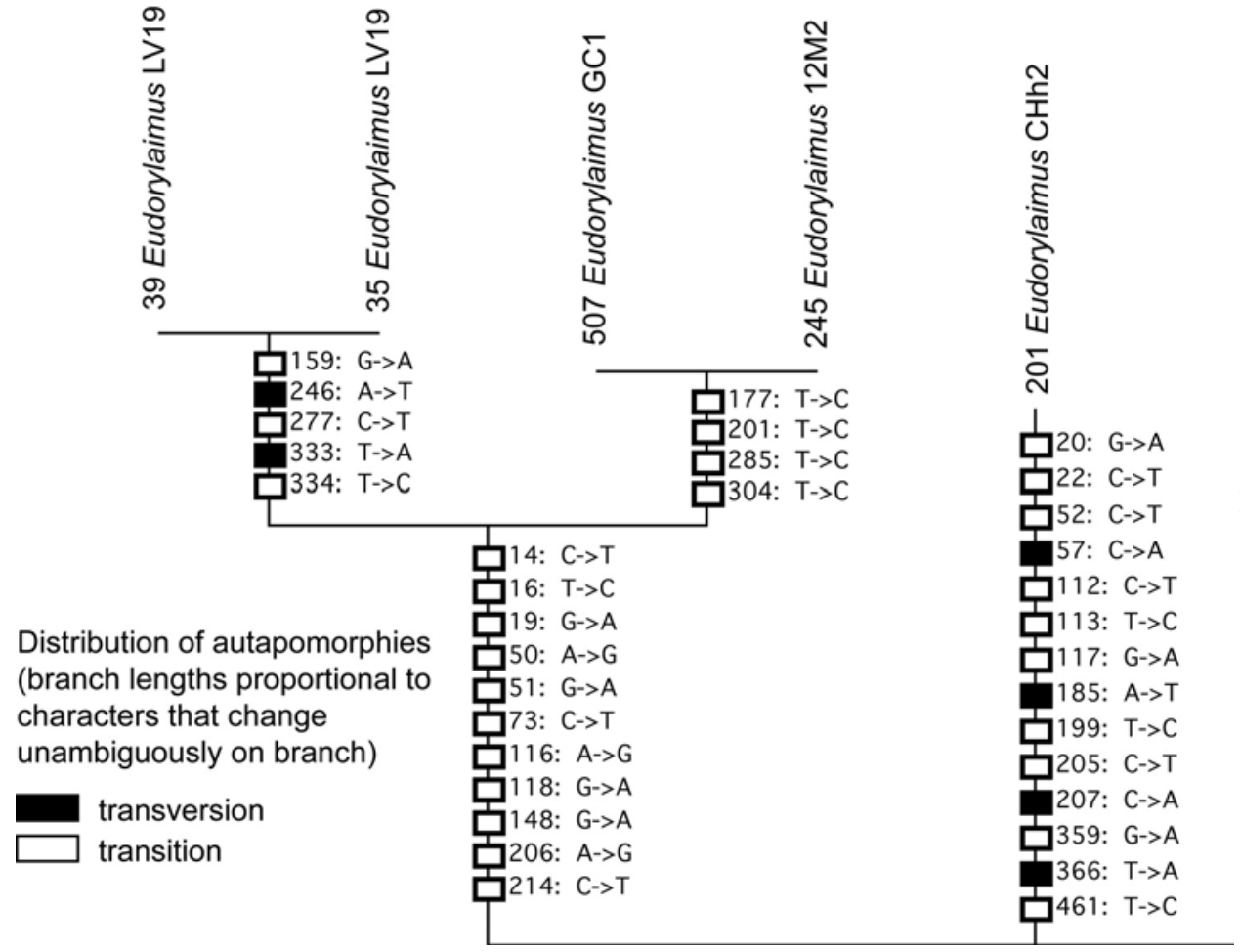

Fig. 4. Cladogram depicting independently evolving lineages of Eudorylaimus. The cladogram was constructed using DNA sequences of the D2/D3 region of the ribosomal large subunit, rooted with Pungentus sylvestris (Genbank accession number AY593052). LV = Luther Vale, GC $=$ Green Creek, $12 \mathrm{M} 2=$ algal mat from Taylor Valley; $\mathrm{CHh} 2=$ Willett Cove. vicinity of Green Creek and Von Guerard Stream (Taylor Valley), Eudorylaimus sp. 2 from Luther Vale, and Eudorylaimus sp. 3 from Willett Cove (Fig. 4).

Total nematode abundance was greatest in soils collected from the Green Creek site, followed by soils collected from the Von Guerard Stream and Willett Cove sites (Fig. 3c, F = 6.95, $P<0.003$ ), and was lowest in soils collected from SeaBee Spit (Fig. 2c). Variability encountered among transects within study sites was also significant, though typically accounted for a smaller proportion of variance than that contributed by differences among sites (Table V). Nematodes were found in a high proportion of soils examined among the study sites relative to previous work (Freckman \& Virginia 1997, Courtright et al. 2001). Ninety percent of soils from the Taylor Valley transects near Von Guerard Stream and Green Creek, $95-100 \%$ of soil from Luther Vale and $70-90 \%$ of the samples examined from Cape Hallett contained nematodes. Soils collected from SeaBee Spit had the highest frequency of instances where no metazoans were present (30\%).

Patterns of metazoan distribution were strongly associated with variation in the availability of soil water and organic matter and species showed distinct habitat preferences. For example, the $\log ($ abundance +1$)$ of Scottnema lindsayae Timm was negatively correlated with soil moisture and organic $\mathrm{C}$ content $(r=-0.52, P<0.0001$ and $r=-0.64, P<0.0001$, respectively); population densities were greatest in soils collected from the Von Guerard transects, followed by Green Creek and the Luther Vale sites (Table IV \& V). S. lindsayae was not found in soils collected from Cape Hallett (Table IV). In contrast, the $\log ($ abundance +1$)$ of Panagrolaimus davidi Timm was strongly correlated with both soil moisture and organic C content $(r=0.62, P<0.0001$ and $r=0.79, P<0.0001$, respectively), and this species was observed only in Cape Hallett soils where it was found in the greatest densities in the Willett Cove transects (Table IV \& V). Plectus antarcticus de Man was observed only in wet soils with low electrical conductivity collected from Green Creek, South Luther Vale, and Willett Cove sites (Table IV). Nematodes of the genus Eudorylaimus were found in the greatest number of sites relative to other metazoans, with the highest abundances observed in soils collected from the vicinity of Green Creek (Table IV, F = 11.46, $P<0.0001$ ).

\section{Bacterial diversity}

We were able to extract high-quality DNA from all samples using the newly developed extraction protocol whereby environmental enzyme inhibitors common in soil extracts using more conventional methods were minimized. Samples containing higher microbial biomass (Table II) provided significantly more DNA (both Dice band-based similarity and densiometric curves, data not shown). As expected, PCR with the bacteria-specific primer set including the forward primer with a G-C clamp resulted in a single 180-bp fragment. These PCR products were purified and quantified prior to DGGE separation to assess qualitative bacterial community composition; replicate DNA extractions from the same soil sample $(n=10)$ 

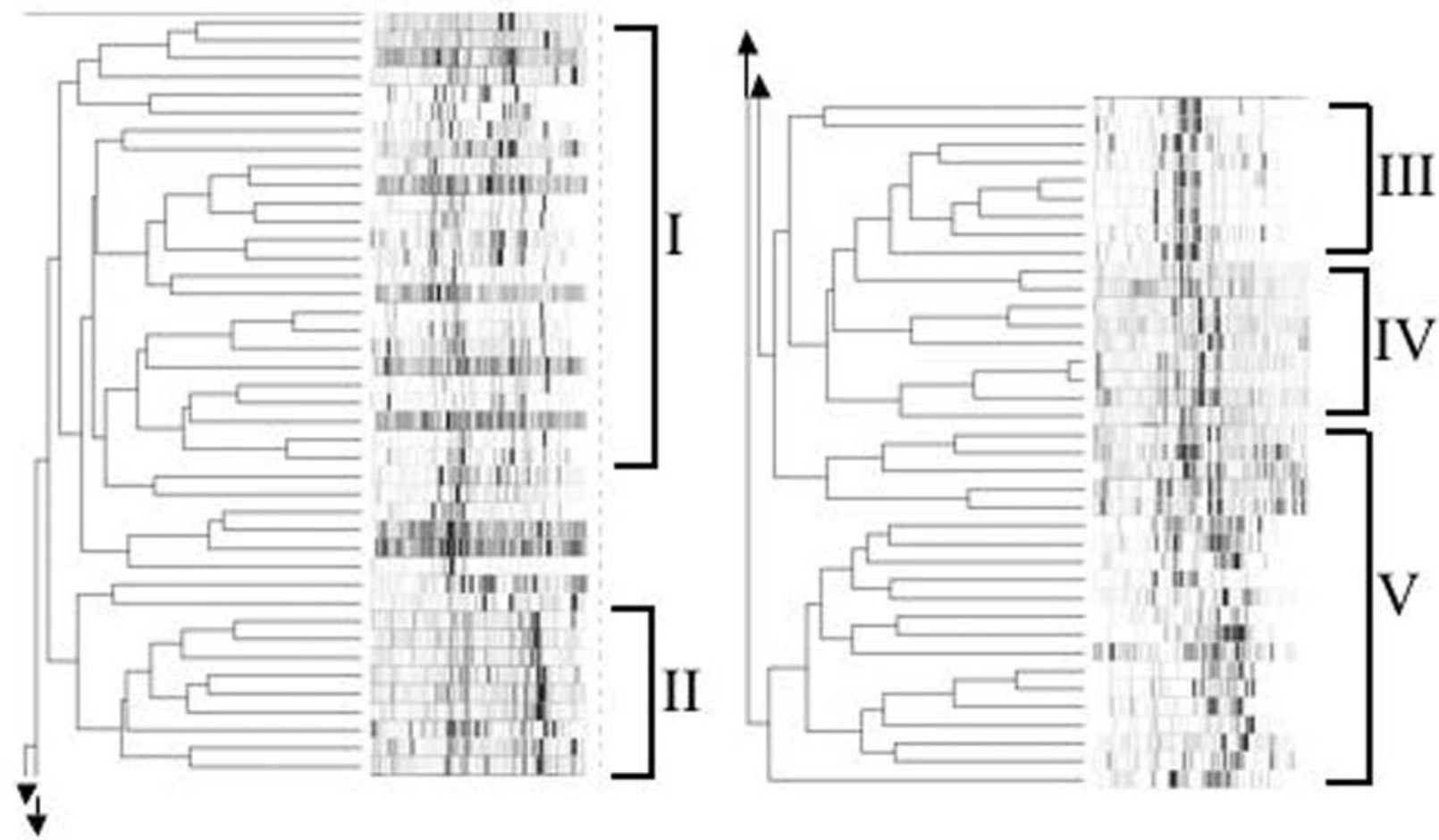

Fig. 5. Cladogram of bacterial populations isolated from Antarctic soils in high and low productivity environments of north and south Victoria Land.

showed highly homogenous DGGE banding patterns.

DGGE profiles revealed an unexpectedly high degree of diversity both within and among soil samples when compared to previous studies, with an average of $9.90 \pm$ 3.23 distinct bands (range 4-21). DGGE profiles also contained regions of increased staining density possibly consisting of merging minor bands. There was no significant difference in number of bands among sampling sites $(\mathrm{F}=0.7, P>0.5, \mathrm{df}=3)$. However, many soils showed unique bacterial assemblages as well as some bands common to many of the soils.

DGGE profiling and subsequent cluster analysis (both Dice band-based similarity and densiometric curves) revealed significant differences in bacterial community structure with the largest effect being the geographic proximity of the soils sampled. For example, bacterial communities from Luther Vale tended to group together in several distinct clusters, while communities from Taylor Valley at Von Guerard and Green Creek generally clustered together (Fig. 5). Four main bacterial groups were associated with various sites from northern and southern Victoria Land (Fig. 5). Those soils that clustered with soils from different field sites did not group with those same soils based on PCA including the biogeochemical properties of soils. There was also a discernable effect based on the a priori designation of the productivity (low vs high) of soils upon bacterial diversity; soils designated as high productivity environments (within individual sites) were more similar to each other than they were to those designated as low productivity environments.

\section{Co-variation in soil biological and biogeochemical parameters}

The PCA plot (Fig. 6) illustrates significant co-variation between soil biota and biogeochemical properties. The first four principal components were selected for the analysis of the total biodiversity-biogeochemistry dataset; they accounted for $67 \%$ of the total variation. The PCA results showed that the first two principal components accounted

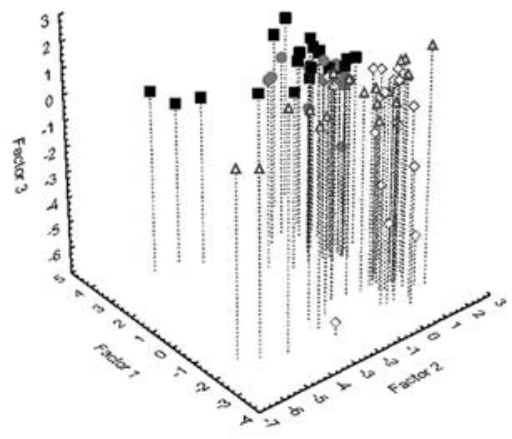

Fryxed Low
$\triangle$ Fryxed High
LV Low

LV Low

Fig. 6. Principle component analyses plot of total dataset (bacterial, metazoan and biogeochemical data). 


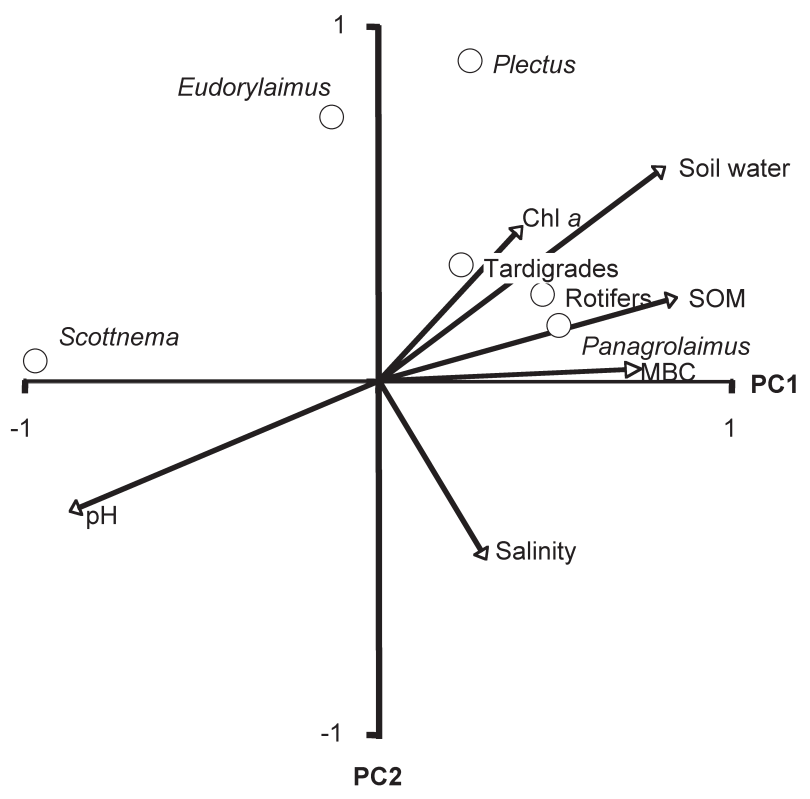

Fig. 7. Principle component analyses plot of metazoan and biogeochemical data.

for a larger portion ( $24 \%$ and $20 \%$, respectively) of the total variability when compared to the subsequent $3 \mathrm{rd}$ and 4 th components (14\% and $9 \%$, respectively). The factor loadings on the first component were large for microbial biomass $\mathrm{C}$ and $\mathrm{N}$, and total soil $\mathrm{N}$. The largest loadings on the second component were for SOC, total moisture and chlorophyll $a$. The third component had large loadings for electrical conductivity (salinity) and both inorganic nitrogen species $\left(\mathrm{NH}_{4}^{+}, \mathrm{NO}_{3}^{-}\right)$. The fourth component had the largest single loading for nematode abundance. The interrelations among the first three components are evident in the projections of components 1, 2, and 3 (Fig. 6). The positions of the samples in 3-dimensional space are related to both the geographic differences among the various sites and their a priori designation as high or low productivity environments.

Four principal components accounted for greater than $96 \%$ of the total variance in the metazoan species and biogeochemical data that we considered independent of the bacterial data. The first two principal components accounted for $82 \%$ of the variance. The factor loadings of the soil biogeochemical data and the metazoan correlations with the first two principal components are plotted in Fig. 7. These data indicate distinct habitat preference for soil metazoans. For example, tardigrades, rotifers and Panagrolaimus davidii are correlated with Principal Component 1, and place within the species-environment biplot in an area representing high levels of chlorophyll $a$, soil moisture, organic matter, and microbial biomass. In contrast,

S. lindsayae was negatively correlated with Principal Component 1 , and was most closely associated with high soil $\mathrm{pH}$ and low moisture and organic matter content.

\section{Discussion}

Regional patterns of soil respiration and biodiversity were strongly associated with variability in biogeochemistry. For example, there was a significant correlation between microbial biomass and maximum rates of soil respiration, while metazoan diversity was highest in wet, organic matter rich soils. Bacterial diversity, as indicated by DGGE band richness, did not vary significantly among the sites considered, though composition of bacterial communities did. These differences in bacterial community structure were mainly associated with geography. DGGE profiles did reveal a relatively high level of bacterial diversity both within and among soil samples consistent with recent descriptions of soils from southern Victoria Land (Cowan et al. 2002, Aislabie et al. 2006, Connell et al. 2006). While DGGE is not very sensitive in detecting rare species, it is a useful index for comparing relative diversity and composition among microbial communities. Our results and others are challenging earlier assumptions and descriptions of limited microbial diversity in Antarctic soils (Cowan et al. 2002, Connell et al. 2006).

Many of the soils examined hosted unique bacterial assemblages while some bands were nearly ubiquitous across all the soils we examined. The distribution of similar bacterial and metazoan taxa across this range of latitudes suggest that dispersal is not a barrier to species distribution (e.g. Moorhead et al. 2003, Nkem et al. 2006); rather, local differences in soil biogeochemistry and physicochemical properties of soils together determine habitat suitability. The lack of a clear relationship between patterns of metazoan and bacterial diversity and community composition suggests that the respective habitat suitability for these different taxa are driven by distinct combinations of these biogeochemical and physical properties. This pattern is also evident in temperate soil ecosystems, (e.g. Black et al. 2003).

There is great interest in the influence of predator/prey dynamics and invertebrate functional types on bacterial community structure and diversity in all soils, though these relationships have proven very difficult to elucidate (Bakonyi 1989, Coleman \& Whitman 2005). To this end, we classified each soil sample based upon its relative abundance of nematodes (Table IV) but there was no visible effect of nematode abundance on bacterial community clustering. Nor was there a significant correlation between DGGE band richness and nematode abundance. These results do not exhibit top-down control over bacterial diversity and biomass mediated by metazoan consumers. Although food webs in the Antarctic are simple relative to nearly all other soils (Wall \& Virginia 1999), the emerging view of biotic and/or trophic interactions in these simple communities is not (Hogg et al. 2006). 


\section{Variation in sources of soil organic matter}

Variation in the stable isotopic composition of soil organic $\mathrm{C}$ and total $\mathrm{N}$ among the sites suggests distinct sources of organic matter, particularly between the low lying coastal sites at Cape Hallett and the higher elevation sites of Taylor Valley and Luther Vale (Fig. 2, e.g. Burkins et al. 2000, Barrett et al. 2006). Differences in ${ }^{15} \mathrm{~N}$ content were more significant than variability in ${ }^{13} \mathrm{C}$, indicating a larger diversity of potential $\mathrm{N}$ source pools relative to $\mathrm{C}$, along with a greater range of isotopic signatures of these source pools. Sources of soil N in Victoria Land are: atmospheric with highly depleted ${ }^{15} \mathrm{~N}$ values (Michalski et al. 2005), in situ $\mathrm{N}_{2}$ fixation with values near atmospheric $\left(\sim 0 \delta{ }^{15} \mathrm{~N}\right.$ $\%$ ), or marine cycled $\mathrm{N}$ with highly enriched values greater than $20 \delta^{15} \mathrm{~N} \%$ (Burkins et al. 2000). Our data indicate that the largest disparities in $\mathrm{N}$ source pools are between soils from Cape Hallett which are influenced by marine $\mathrm{N}$ sources, and those from Taylor Valley which have atmospheric to slightly depleted values (Fig. 2). Though it is not possible to distinguish between marine aerosols and sea bird guano as sources to Cape Hallett soils, the large concentrations of organic matter and $\mathrm{NH}_{4}^{+}$suggest that direct input from sea birds is a much more important source than marine aerosols. The ${ }^{13} \mathrm{C}$ values of some soils are greater than the average values for $\mathrm{C}_{3}$ photosynthesis, and may indicate in situ enrichment of organic matter following microbial degradation. The broader range of ${ }^{13} \mathrm{C}$ content for Taylor Valley and Luther Vale may indicate a larger number of potential contributors to soil organic matter that may include $\mathrm{C}$ fixed by marine, lacustrine, endolithic and in situ phototrophs (Burkins et al. 2000, Lawson et al. 2004).

The higher elevation areas in northern Victoria Land do not receive significant marine inputs and consequently the soil organic matter concentrations and isotopic signatures are more similar to the dry valleys than to neighboring Cape Hallett, indicating a terrestrial source of organic matter, i.e. algae, moss and lichens. Soil metazoan communities are also similar to the dry valleys, with the nematode S. lindsayae dominating faunal populations (Freckman \& Virginia 1997). These similarities between Luther Vale and the dry valleys suggest that the source of $\mathrm{C}$ (algal vs ornithogenic) is a key factor in structuring soil invertebrate communities.

\section{Controls over habitat suitability}

Soil biogeochemical variables shared significant variance, which is illustrated by the clustering of environmental factor loadings in the PCA (Figs 6 \& 7). For example, wet sites tended to be rich in organic matter and microbial biomass $\mathrm{C}$, and these variables were strongly correlated with Principal Component 1 (Fig. 7). Saline, or alkaline soils were either negatively correlated or orthogonal to Principal Component 1 and these generally favorable site conditions for metazoans (Fig. 7). These underlying biogeochemical properties are important influences over the distribution of soil organisms, though the response of individual species to different soil properties varied. For example, S. lindsayae inhabits a quadrant of the Principal Component bi-plot that is strongly correlated with $\mathrm{pH}$, while Panagrolaimus davidii, Rotatoria and tardigrades were most abundant in wet, organic matter rich soils (Fig. 7). Thus different metazoan taxa manifest distinct habitat preferences.

Abundance and distribution of S. lindsayae was unrelated to a priori designations of productivity across transect or latitudes (Table IV \& V), or to observed levels of soil organic matter, nutrients and soil respiration (Table II). Numerous studies have demonstrated that this species is well adapted to the arid, nutrient poor habitats that are ubiquitous throughout Victoria Land (e.g. Freckman \& Virginia 1997, Treonis et al. 1999, Courtright et al. 2001). In contrast, Plectus antarcticus and Panagrolaimus davidii were confined to narrowly defined and spatially restricted habitats. Plectus antarticus is found only in wet to intermittently wet soils and sediments where salinity is low (Treonis et al. 1999), while Panagrolaimus davidii inhabits the wet, nutrient rich habitats of rookeries and adjacent soils (Porazinska 2002), that are evidently inhospitable to most other metazoans (e.g. Sinclair et al. 2003), as indicated by the lower diversity and biomass of organisms reported here (Fig. 3, Table III). Penguin rookeries are likely to be unsuitable habitats for most metazoans because of the elevated levels of organic acids, $\mathrm{NH}_{4}^{+}$and $\mathrm{NO}_{3}{ }^{-}$associated with ornithogenic soils (Cocks et al. 1998). Differences in nematode distribution may also be related to feeding preferences. For example, Panagrolaimus davidi is a bacterial feeder and may favor ornithogenic soils where culturable bacteria are plentiful relative to sites in southern Victoria Land, while S. lindsayae, a yeast and bacterial feeder, may have an advantage in the dry valleys where fungi are more abundant (Connell et al. 2006, Aislabie unpublished).

In contrast to the other nematodes, the genus Eudorylaimus is found throughout Victoria Land, in dry to wet soils and sediments $\left(2-20 \% \mathrm{~g} \mathrm{~g}^{-1}\right)$ of the McMurdo Dry Valleys (Freckman \& Virginia 1997, Powers et al. 1998, Treonis et al. 1999, Courtight et al. 2001, Barrett et al. 2004), and saturated soils under algal mats and moss communities in northern Victoria Land (Table IV). The only habitats where Eudorylaimus spp. was not found were in the soils of SeaBee Spit, adjacent to active penguin mounds. This broad environmental tolerance may be related to the genetic variation encountered among the Eudorylaimus individuals. Our data indicate that there are at least three species of this genus occupying the distinct sites where it was present (Fig. 4). Thus greater taxonomic resolution revealed important, though subtle differences in habitat preference among three morphologically indistinguishable 
species. It is also significant that these three species occur across three out of four of the sites where distinct bacterial communities were identified through DGGE analysis. These results suggest that greater scrutiny of previously identified taxonomic groups may yield greater ecological insight to controls over their distribution and perhaps the potential for biotic interaction among metazoan and microbial taxa.

\section{Conclusions}

Soil biodiversity varied across the latitudinal gradient studied, with the most significant differences encountered among sites with distinct sources and concentrations of soil organic matter and physicochemical properties. There were no apparent differences in bacterial diversity among the sites considered, though composition of bacterial communities was significantly different. There was no correlation between bacterial diversity and invertebrate abundance or diversity suggesting that controls over microbial diversity are not mediated by higher trophic level communities (and vice versa). The limited number of sites, and their uneven distribution across the gradient prevents conclusions about latitudinal and/or climate controls over patterns of soil biodiversity. However, significant heterogeneity in edaphic factors among sites contributed to variability in distribution and abundance of soil biota. This suggests that broad scale trends in soil chemistry, for example, the availability and composition of organic matter or the concentration of salts, are important influences over the composition of soil communities.

\section{Acknowledgements}

This work was supported by the National Science Foundation (OPP \#02-29836) and the McMurdo Long Term Ecological Research Project (OPP \#98-10219). We thank J. Nkem for assistance with invertebrate identification and enumeration, and M. Poage for assistance with stable isotope measurements. Logistical support was provided by Antarctica New Zealand, Raytheon Polar Services and Petroleum Helicopters Inc. Special thanks to Shulamit Gordon, Gus McAllister and Rachel Brown of Antarctica New Zealand for field and logistical support.

\section{References}

ADAMS, B.J. 1998. Species concepts and the evolutionary paradigm in modern nematology. Journal of Nematology, 30, 1-21.

ADAMs, B.J. 2001. The species delimitation uncertainty principle. Journal of Nematology, 33, 153-160.

Adams, B.J., Bardgett, R., Ayres, D.E., Wall, D.H., Aislabie, J., Bamforth, S., Bagagli, R., Cary, S.C., Cavacini, P., Connell, L., Convey, P., Fell, J., Frati, F., Hogg, I., Newsham, K., O’Donnell, T., Russell, N., Seppelt, R. \& Stevens, M.I. 2006. Diversity and distribution of Victoria Land biota. Soil Biology and Biochemistry, 38, 3003-3018
Aislabie, J., ChHour, K., Saul, D.J., Miyauchi, S., Ayton, J., Paetzold, R.F. \& BALKs, M.R. 2006. Dominant bacterial groups in soils of Marble Point and Wright Valley, Victoria Land, Antarctica. Soil Biology and Biochemistry, 38, 3041-3056.

Alger, A.S., McKnight, D.M., Spaulding, S.A., Tate, C.M., Shupe, G.H., Welch, K.A., EdWARds, R. \& House, H.R. 1997. Ecological processes in a cold desert ecosystem: the abundance and species of algal mats in glacial meltwater streams in Taylor Valley, Antarctica. INSTAAR Occasional Paper, 51, 108 pp.

ANDRASSY, I. 1998. Nematodes in the sixth continent. Journal of Nematode Morphology and Systematics, 1, 107-186.

Bakonyi, G. 1989. Effects of Folsomia candida (Collembola) on the microbial biomass in a grassland soil. Biology and Fertility of Soils, 7, 138-141.

Baldwin, J.G., Giblin-Davis, R.M., Eddleman, C.D., Williams, D.S., VIDA, J.T. \& THOMAS, W.K. 1997. The buccal capsule of Aduncospiculum halicti (Nematoda: Diplogasterina): an ultrastructural and molecular phylogenetic study. Canadian Journal of Zoology, 75, 407-423.

Bargagli, R., Smith, R.I.L., Martella, L., Monaci, F., SanchezHeRnANDEZ, J.C. \& UGOLINI, F.C. 1999. Solution geochemistry and behaviour of major and trace elements during summer in a moss community at Edmonson Point, Victoria Land, Antarctica. Antarctic Science, 11, 3-12.

Barrett, J.E., Virginia, R.A. \& Wall, D.H. 2002. Trends in resin and $\mathrm{KCl}$-extractable soil nitrogen across landscape gradients in Taylor Valley, Antarctica. Ecosystems, 5, 289-299.

Barrett, J.E., Wall, D.H., Virginia, R.A., Parsons, A.N., Powers, L.E. \& BURKINS, M.B. 2004. Biogeochemical parameters and constraints on the structure of soil biodiversity. Ecology, 85, 3105-3118.

Barrett, J.E., Virginia, R.A., Hopkins, D.W., Aislabie, J., Bargagli, R., Bockheim, J.G., Campbell, I. B., Lyons, W. B., Moorhead, D., Nkem, J., Sletten, R., Steltzer, H., Wall, D. H. \& Wallenstein, M. 2006. Terrestrial ecosystem processes of Victoria Land, Antarctica. Soil Biology and Biochemistry, 38, 3019-3034.

Black, H.I.J., Parekh, N.R., Chaplow, J.S., Monson, F., Watkins, J., Creamer, R., Potter, E.D., Poskitt, J.M., Rowland, P., Ainsworth, G. \& HoRnung, M. 2003. Assessing soil biodiversity across Great Britain: national trends in the occurrence of heterotrophic bacteria and invertebrates in soil. Journal of Environmental Management, 67, 255-266.

Blaxter, M., Mann, J., Chapman, T., Thomas, F., Whitton, C., Floyd, R. \& ABEBE, E. 2005. Defining operational taxonomic units using DNA barcode data. Philosophical Transactions of the Royal Society, B360, 1935-1943.

Burkins, M.B., Virginia, R.A., Chamberlain, C.P. \& Wall, D.H. 2000. Origin and distribution of soil organic matter in Taylor Valley, Antarctica. Ecology, 81, 2377-2391.

Burkins, M.B., Virginia, R.A. \& Wall, D.H. 2001. Organic carbon cycling in Taylor Valley, Antarctica: quantifying soil reservoirs and soil respiration. Global Change Biology, 7, 113-125.

CAmpBell, I.B. \& Claridge, G.G.C. 1982. The influence of moisture on the development of soils of the cold deserts of Antarctica. Geoderma, 28, 221-238.

CAmpbell, I.B. \& Claridge, G.G.C. 1987. Antarctica: soils, weathering processes and environment. Amsterdam: Elsevier, $368 \mathrm{pp}$.

CHENG, W.X. \& VIRGINIA, R.A. 1993. Measurement of microbial biomass in arctic tundra soils using fumigation extraction and substrate-induced respiration procedures. Soil Biology \& Biochemistry, 25, 135-141.

Cherry, T., Szalanski, A.L., Todd, T.C. \& Powers, T.O. 1997. The internal transcribed spacer region of Belonolaimus (Nemata: Belonolaimidae). Journal of Nematology, 29, 23-29.

Cocks, M.P., Newton, I.P. \& Stock, W.D. 1998. Bird effects on organic processes in soils from five microhabitats on a nunatak with and without breeding snow petrels in Dronning Maud Land, Antarctica. Polar Biology, 20, 112-120. 
Coleman, D.C. \& Whitman, W.B. 2005. Linking species richness, biodiversity and ecosystem function in soils systems. Pedobiologia, 49, 479-497.

Connell, L., Redman, R., Craig, S. \& Rodriguez, R. 2006. Distribution and abundance of fungi in soils of Taylor Valley, Antarctica. Soil Biology and Biochemistry, 38, 3083-3094.

Convey, P. \& Wynn-Williams, D.D. 2002. Antarctic soil nematode response to artificial climate amelioration. European Journal of Soil Biology, 38, 255-259.

Convey, P. \& McInnes, S.J. 2005. Exceptional tardigrade-dominated ecosystems in Ellsworth Land, Antarctic. Ecology, 86, 519-527.

Coyne, K.J., Hutchins, D.A., Hare, C.E. \& CARY, S.C. 2001. Assessing temporal and spatial variability in Pfiesteria piscicida distributions using molecular probing techniques. Aquatic Microbial Ecology, 24, 275-285

Courtright, E.M., Wall, D.H. \& Virginia, R.A. 2001. Determining habitat suitability for soil invertebrates in an extreme environment: the McMurdo Dry Valleys, Antarctica. Antarctic Science, 13, 9-17.

Cowan, D.A., Russell, N.J., Mamais, A. \& Sheppard, D.M. 2002. Antarctic Dry Valley mineral soils contain unexpectedly high levels of microbial biomass. Extremophiles, 6, 431-436.

D’Aquila, R.T., Bechtel, L.J., Videler, J.A., Eron, J.J., Gorczyca, P. \& KAPLAN, J.C. 1991. Maximizing sensitivity and specificity of PCR by preamplification heating. Nucleic Acids Research, 19, 3749-3749.

Doran, P.T., McKay, C.P., Clow, G.D., Dana, G.L., Fountain, A.G., Nylen, T. \& LyONS, W.B. 2002a. Valley floor climate observations from the McMurdo Dry Valleys, Antarctica, 1986-2000. Journal of Geophysical Research, 107, 4772-4784.

DupHORN, K. 1981. Physiographical and glaciogeological observations in north Victoria Land, Antarctica. Geologische Jahrbuch, B41, 89-109.

Elberling, B., Gregorich, E.G., Hopkins, D.W., Sparrow, A.D., Novis, P. \& Greenfield, L.G. 2006. Distribution and dynamics of soil organic matter in an Antarctic dry valley. Soil Biology and Biochemistry, 38, 3095-3106.

Eyualem, A. \& Blaxter, M. 2003. Comparison of biological, molecular, and morphological methods of species identification in a set of cultured Panagrolaimus isolates. Journal of Nematology, 35,119-128.

Floyd, R., Abebe, E., Papert, A. \& Blaxter, M. 2002. Molecular barcodes for soil nematode identification. Molecular Ecology, 11, 839-850.

Freckman, D.W. \& Virginia, R.A. 1997. Low-diversity Antarctic soil nematode communities: distribution and response to disturbance. Ecology, 78, 363-369.

Friedmann, E.I., Kappen, L., Meyer, M.A. \& Nienow, J.A. 1993. Longterm productivity in the cryptoendolithic microbial community of the Ross Desert, Antarctica. Microbial Ecology, 25, 51-69.

Frost, D.R. \& Kluge, A.G. 1994. A consideration of epistemology in systematic biology, with special reference to species. Cladistics, 10, 259-294.

Gooseff, M.N., Barrett, J.E., Doran, P.T., Lyons, W.B., Parsons, A.N., Porazinska, D.L., Virginia R.A. \& Wall, D.H. 2003. Snow-patch influence on soil biogeochemical processes and invertebrate distribution in the McMurdo Dry Valleys, Antarctica. Arctic, Antarctic, and Alpine Research, 35, 92-100.

Gregorich, E.G., Hopkins, D.W., Elberling, B., Sparrow, A.D., Novis, P., Greenfield, L.G. \& Rochette, P. 2006. Biogenic gas emission from lakeshore soils in an Antarctic dry valley. Soil Biology and Biochemistry, 38, 3120-3129.

Hogg, I., Cary, S.C., O’Donnell, A., Newsham, K., Adams, B.J., Aislabie, J., Convey, P., Frati, F., Stevens, M. \& Wall, D.H. 2006. Biotic interactions in Antarctic terrestrial ecosystems: are they a factor? Soil Biology and Biochemistry, 38, 3035-3040.
Howard-Williams, C., Peterson, D., Lyons, W.B., Cattaneo-Vietti, R. \& Gordon, S. 2006. Measuring ecosystem response in a rapidly changing environment: the Latitudinal Gradient Project. Antarctic Science, 18, 465-471.

Kappen, L., Schroeter, B., Green, T.G.A. \& Seppelt, R.D. 1998. Microclimatic conditions, meltwater moistening, and the distributional pattern of Buellia frigida on rock in a southern continental Antarctic habitat. Polar Biology, 19, 101-106.

Lawson J., Doran, P.T., Kenig F., Des Marais, D.J. \& Priscu, J.C. 2004. Stable carbon and nitrogen isotopic composition of benthic and pelagic organic matter in lakes of the McMurdo Dry Valleys, Antarctica. Aquatic Geochemistry, 10, 269-301.

Lee, C.H., Lu, J.J., Tang, X., Jiang, B.D., Li, B.Z., Jin, S.L., Bartlett, M.S., Lundgren, B., Atzori, C., Orlando, G., Cargnel, A. \& Smith, J.W. 1996. Prevalence of various Pneumocystis carinii sp. f. hominis types in different geographical locations. Journal of Eukaryotic Microbiology, 43, S37-S37

Lessa, E.P. \& Applebaum, G. 1993. Screening techniques for detecting allelic variation in DNA sequences. Molecular Ecology, 2, 119-129.

LYNCH, J.D. 1999. Ranas pequeñas, la geometrîa de evolution, y la especiacion en los Andes Colombianos. Revista de la Academia Colombiana de Ciencias Exactas, Fîsicas y Naturales, 184, 143-159.

LyNCH, J.D. \& RENJifo, J.M. 1990. Two new toads (Bufonidae: Rhamphophryne) form the northern Andes of Colombia. Journal of Herpetology, 24, 364-371.

McKnight, D.M., Runkel, R.L., Tate, C.M., Duff, J.H. \& Moorhead, D.L. 2004. Inorganic $\mathrm{N}$ and $\mathrm{P}$ dynamics of Antarctic glacial meltwater streams as controlled by hyporheic exchange and benthic autotrophic communities. Journal of the North American Benthological Society, 23, 171-188.

Michalski, G., Bockheim, J.G., Kendall, C. \& Thiemens, M. 2005. Isotopic composition of Antarctic Dry Valley nitrate: implication for $\mathrm{NO}_{\mathrm{y}}$ sources and cycling in Antarctica. Geophysical Research Letters, 32, L13817.

Moorhead, D.L., Barrett, J.E., Virginia, R.A., Wall, D.H. \& PorazINSKA, D. 2003. Organic matter and soil biota of upland wetlands in Taylor Valley, Antarctica. Polar Biology, 26, 567-576.

Murray, A.E., Hollibaugh, J.T. \& Orrego, C. 1996. Phylogenetic compositions of bacterioplankton from two California estuaries compared by denaturing gradient gel electrophoresis of $16 \mathrm{~S}$ rDNA fragments. Applied Environmental Microbiology, 62, 2676-2680.

Muyzer, G., De Waal, E.C. \& Uitterlinden, A.G. 1993. Profiling of complex microbial populations by denaturing gradient gel electrophoresis analysis of polymerase chain reaction-amplified genes coding for $16 \mathrm{~S}$ rRNA. Applied Environmental Microbiology, 59, 695-700.

Myers, R.M., SHEFFIELD, R. \& Cox, D.R. 1988. Detection of single base changes in DNA: Ribonuclease cleavage and denaturing gradient gel electrophoresis. Genome analysis: a practical approach. Oxford: IRL Press, 95-139

Nadler, S.A., Adams, B.J., Lyons, E.T., Delong, R.L. \& Melin, S.R. 2000. Molecular and morphometric evidence for separate species of Uncinaria (Nematoda: Ancylostomatidae) in California sea lions and northern fur seals: hypothesis testing supplants verification. Journal of Parasitology, 86, 1099-1106.

Nkem, J.N., Virginia, R.A., Barrett, J.E., Wall, D.H. \& Li, G. 2006. Salt tolerance and survival thresholds for two species of Antarctic soil nematodes. Polar Biology, 29, 643-651.

PAlmer, M.W. 1993. Putting things in even better order: the advantages of Canonical Correspondence Analysis. Ecology, 74, 2215-2230.

Pannewitz, S., Green, T.G.A., Scheidegger, C., Schlensog, M. \& Schroeter, B. 2003. Activity pattern of the moss Hennediella heimii (Hedw.) Zand. in the Dry Valleys, Southern Victoria Land, Antarctica during the mid-austral summer. Polar Biology, 26, 545-551. 
Pannewitz, S., Green, T.G.A., Maysek, K., Schlensog, M., Seppelt, R.D., SAncho, L.G., TÜrk, R. \& Schroeter, B. 2005. Photosynthetic responses of three common mosses from continental Antarctica. Antarctic Science, 17, 341-352.

Parsons, A.N., Barrett, J.E., Wall, D.H. \& Virginia, R.A. 2004. Carbon-dioxide flux from Antarctic Dry Valley soils. Ecosystems, 7, 286-295.

Petz, W. 1997. Ecology of the active soil microfauna (Protozoa, Metazoa) of Wilkes Land, East Antarctica. Polar Biology, 18, 33-44.

Polz, M.F. \& Cavanaugh, C.M. 1998. Bias in template-to-product ratios in multi-template PCR. Applied and Environmental Microbiology, 64, 3724-3730

PORAZINSKA, D.L., WALL, D.H. \& VIRGINIA, R.A. 2002. Invertebrates in ornithogenic soils on Ross Island, Antarctica. Polar Biology, 25, 569-574.

Powers, L.E., Ho, M., Freckman, D.W. \& Virginia, R.A. 1998 Distribution, community structure, and microhabitats of soil invertebrates along an elevational gradient in Taylor Valley, Antarctica. Arctic and Alpine Research, 30, 133-141.

Raytheon Polar Services Company. 2003. Hallett Station Site Characterisation Report. Raytheon Technical Services Company, Colorado, USA, 50 pp. [Unpublished].

RudolPh, E.D. 1963. Vegetation of Hallett Station area, Victoria Land, Antarctica. Ecology, 44, 585-586.

Saiki, R.K., Gelfand, D.H., Stoffel, S., Scharf, S.J., Higuchi, R., Horn, G.T., Mullis, K.B. \& ERLich, H.A. 1988. Primer-directed enzymatic amplification of DNA with a thermostable DNA-polymerase. Science, 239, 487-491

Schwarz, A.M.J., Green, T.G.A. \& Seppelt, R.D. 1992. Terrestrial vegetation at Canada Glacier, Southern Victoria Land, Antarctica. Polar Biology, 12, 397-404.

Schwarz, A.M.J., Green, J.D., Green, T.G.A. \& Seppelt, R.D. 1993. Invertebrates associated with moss communities at Canada Glacier, southern Victoria Land, Antarctica. Polar Biology, 13, 157-162.

SincLaIR, B.J. 2001. On the distribution of terrestrial invertebrates at Cape Bird, Ross Island, Antarctica. Polar Biology, 24, 394-400.
Sinclair, B.J., Klok, C.J., Scott, M.B., Terblanche, J.S. \& Chown, S.L 2003. Diurnal variation in supercooling points of three species of Collembola from Cape Hallett, Antarctica. Journal of Insect Physiology, 49, 1049-1061.

Sohlenius, B., Bostrom, S. \& Jonsson, K.I. 2004. Occurrence of nematodes, tardigrades and rotifers on ice-free areas in East Antarctica Pedobiologia, 48, 395-408.

SoKAL, R.R. \& Michener, C.D. 1958. A statistical method evaluating systematic relationships. Science Bulletin, University of Kansas, 38 , 1409-1438.

SuZuKi, M.T. \& GiovanNonI, S.J. 1996. Bias caused by template annealing in the amplification of mixtures of $16 \mathrm{~S}$ rRNA genes by PCR. Applied and Environmental Microbiology, 62, 625-630.

Ter BraAk, C.J.F. 1986. Canonical correspondence analysis: a new eigenvector technique for multivariate direct gradient analysis. Ecology, 67, 1167-1179.

Treonis, A.M., Wall, D.H. \& VIRginia, R.A. 1999. Invertebrate biodiversity in Antarctic Dry Valley soils and sediments. Ecosystems, 2 482-492.

Treonis, A.M., Wall, D.H. \& Virginia, R.A. 2000. The use of anhydrobiosis by soil nematodes in the Antarctic Dry Valleys. Functional Ecology, 14, 460-467.

Virginia, R.A. \& WALL, D.H. 1999. How soils structure communities in the Antarctic dry valleys. Bioscience, 49, 973-983.

VRain, T.C., WaKarchuK, D.A., Levesque, A.C. \& Hamilton, R.I. 1992. Intraspecific rDNA restriction fragment length polymorphism in the Xiphinema americanum group. Fundamental and Applied Nematology, $15,563-574$

WALL, D.H. \& VIRGINIA, R.A. 1999. Controls on soil biodiversity: insights from extreme environments. Applied Soil Ecology, 13, 137-150.

WiLEY, E.O. 1978. The evolutionary species concept reconsidered. Systematic Zoology 27, 17-26.

Wiley, E.O. \& MAYDEN, R.L. 2000. The evolutionary species concept. In Wheeler, Q.D. \& MeIER, R., eds. Species concepts and phylogenetic theory: a debate. New York: Columbia University Press, 70-224. 